This is a peer-reviewed version of article

Skorić Marijana ${ }^{\mathrm{a}}$, Gligorijević Nevenka ${ }^{\mathrm{b}}$, Čavić Milena ${ }^{\mathrm{b}}$, Todorović Slađana ${ }^{\mathrm{a}}$, Janković Radmila $^{\mathrm{b}}$, Ristić Mihailo ${ }^{\mathrm{c}}$, Mišić Danijela ${ }^{\mathrm{a}}$, Radulović Siniša ${ }^{\mathrm{b}}$. "Cytotoxic activity of Nepeta rtanjensis Dikli'c \& Milojevi'c essential oiland its mode of action.“ Industrial Crops and Products, 2017,100:163-170. http://dx.doi.org/10.1016/j.indcrop.2017.02.027

This work was supported by the Ministry of Education and Science of the Republic of Serbia (Contracts No. 173024, No. III41026 and No. 173021)

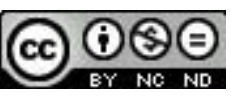

This work is licensed under a Creative Commons Attribution 4.0 International License. 


\section{Cytotoxic activity of Nepeta rtanjensis Diklić \& Milojević essential oil and its mode of action}

Skorić Marijana ${ }^{\mathrm{a}}$, Gligorijević Nevenka ${ }^{\mathrm{b}}$, Čavić Milena ${ }^{\mathrm{b}}$, Todorović Slađana ${ }^{\mathrm{a}}$, Janković

Radmila $^{\mathrm{b}}$, Ristić Mihailo ${ }^{\mathrm{c}}$, Mišić Danijela ${ }^{\mathrm{a}}$, Radulović Siniša ${ }^{\mathrm{b}}$

a. Institute for Biological Research "Siniša Stanković”, University of Belgrade, Bulevar despota Stefana 142, 11000 Belgrade, Serbia

b. Institute for Oncology and Radiology of Serbia, Pasterova 14, 11000 Belgrade, Serbia

c. Institute for Medicinal Plants Research "Dr Josif Pančić”, Tadeuša Košćuška 1, 11000 Belgrade, Serbia

Corresponding author:

Skorić Marijana, Institute for Biological Research "Siniša Stanković", University of Belgrade, Bulevar despota Stefana 142, 11000 Belgrade, Serbia,

email address mdevic@ibiss.bg.ac.rs 


\begin{abstract}
Nepeta rtanjensis Diklić \& Milojević (fam. Lamiaceae) is an endemic, critically endangered plant, protectedby the law in Serbia. Various biological activities have been ascribed to its major constituents, nepeta-lactones. In this study we describe for the first time cytotoxic activity of N. rtanjensis essential oil (EO),obtained from field cultivated plants, which was found to be especially rich in trans,cis-nepetalactone.MTT assays indicated that after $72 \mathrm{~h}$ of treatment the EO exhibited cytotoxic activity on investigatedcancer cell lines: HeLa, K562, A549, LS-174 and MDA-MB-231. Normal cell line (MRC-5) was the leastsensitive to the treatment and IC50value for this cell line was not reached within the tested range ofEO concentrations (up to $0.1 \mathrm{~L} / \mathrm{mL}$ ). Analysis of morphological changes of treated cells confirmed thehigher sensitivity of tumor cells than normal cells to the tested EO. Application of N. rtanjensis EO resultedin the appearance of morphological changes in tested cancer cell lines characteristic for apoptotic celldeath, and induced perturbations of the cell cycle of HeLa cells. In addition, upregulation of Bax and p53, and downregulation of Bcl-2, and Skp2 genes, involved in apoptotic signalling cascades, confirmed anapoptosis-inducing effect of $\mathrm{N}$. rtanjensis EO on HeLa cells. Presented results highlighted the potential ofN. rtanjensis EO in anticancer therapy.
\end{abstract}

Key words: Anticancer activity, Apoptosis, Nepeta rtanjensis, cis-nepetalctone

\footnotetext{
Abbreviations:

EO, essential oil; GC, gas chromatography; HeLa, humancervix carcinoma cells; MDA-MB-231, human breast cancer cells; LS-174, human colon carcinoma cells; A549, lung adenocarcinoma cells; K562, humanmyelogenous leukemia cells; MRC-5, human fetal lung fibroblast cells; MTT, 3-(4,5-dimethylthiazol2yl)-2,5-diphenyltetrazolium bromide.
} 


\section{INTRODUCTION}

Nepeta rtanjensis Diklić \& Milojević (fam. Lamiaceae) belongs tothe genus Nepeta (catmints), which comprises species that con-tain a variety of secondary metabolites belonging to terpenoids(monoterpenoids, diterpenoids, triterpenoids, sesquiterpenoids)and phenolics (Formisano et al., 2011; Sharma and Cannoo, 2013; Mišić et al., 2015). Numerous Nepeta species are traditionally usedfor the treatment of different gastrointestinal and respiratory dis-orders such as colic, diarrhea, cough and asthma due to spasmolyticand myorelaxant activities (Gilani et al., 2009; Formisano et al.,2011). These plants exhibit effects as cats and aphids attractant (Sakurai et al., 1988; Formisano et al., 2011), or act as repellentsagainst various insects such as mosquitoes, ixodid ticks and redpoultry mites (Birkett et al., 2011). Antimicrobial activity againsta variety of bacteria and fungi, antioxidant and phytotoxic activi-ties of Nepeta plants have been well documented (Stojanović et al.,2005; Tepe et al., 2007; Ljaljević Grbić et al., 2008; Nestorović et al.,2010; Formisano et al., 2011; Kumar et al., 2014). Furthermore, these plants have shown antiviral, phytotoxic and allelopathiceffects (Kobaisy et al., 2005; Formisano et al., 2011; Dmitrović et al.,2015; Nestorović Zivković et al., 2016). Several studies investigatedthe cytostatic and cytotoxic activities of various Nepeta species(Rigano et al., 2011; Tsuruoka et al., 2012; Kahkeshani et al., 2014; Shakeri et al., 2014, 2016). The majority of aforementioned bio-logical activities of Nepeta species are ascribed to nepetalactones,cyclopentanoid monoterpenes which are usually the main con-stituents of the essential oils (Birkett et al., 2011; Formisano et al.,2011; Stojanović et al., 2005; Nestorović et al., 2010; Kumar et al.,2014; Mišić et al., 2015). Certain Nepeta species (Nestorović et al.,2010; Sharma and Cannoo, 2013) do not produce 
nepetalactones(or produce them in small amounts), thus their biological activ-ity could be attributed to other terpenoid or phenolic compounds (Nestorović et al., 2010; Formisano et al., 2011; Mišić et al., 2015). The biological activity of nepetalactones depends on their stereochemistry (Gkinis et al., 2003; Nestorović et al., 2010). There areeight stereoisomers of nepetalactone, four diastereoisomers andtheir corresponding enantiomers, and with some exceptions, onlythe (7S)-diastereomers exist in natural sources (Formisano et al.,2011).

N. rtanjensis Diklić \& Milojević is listed in Red Data Book of Floraof Serbia as critically endangered plant species which belongs tothe aggr. N. sibthorpii (Diklić, 1999). It is a rare and strictly endemicperennial found only in a few localities of Mt Rtanj in NorthEastSerbia (Diklić, 1999; Mišić et al., 2005). Therefore, in vitro plantpropagation, field cultivation and reintroduction were performed (Mišić et al., 2005) in order to obtain sufficient plant material forthe investigation of biological activities (Ljaljević Grbić et al., 2008; Nestorović et al., 2010; Dmitrović et al., 2015; Nestorović Živković cet al., 2016). Until now various biological activities of N. rtanjen-sis are well demonstrated: antibacterial (Stojanović et al., 2005; Nestorović et al., 2010), antifungal (Stojanović et al., 2005; Ljaljević Grbić et al., 2008; Nestorović et al., 2010), allelopathic (Nestorović Živković et al., 2016), and phytotoxic (Dmitrović et al., 2015). Theessential oil (EO) of N. rtanjensis is characterized by a high content oftrans-cis nepetalactone which is considered to be the main compo-nent principally responsible for the biological activities (Stojanovi'cet al., 2005; Nestorovi'c et al., 2010; Mišić et al., 2015). To our knowl-edge there are no data about the cytotoxic activities of this EO.

EOs and/or their individual components are widely used fortreatment of various human diseases including cancer (Edris, 2007; Bhalla et al., 2013; Saad et al., 2013; Raut and Karuppayil, 2014). EOs exhibit direct anticancer activity on numerous human can-cer cell 
lines and have positive effects in chemoprevention due totheir antioxidant, antiproliferative and antimutagenetic activities(Bhalla et al., 2013; Saad et al., 2013; Raut and Karuppayil, 2014). Furthermore EOs could inhibit process of angiogenesis, enhanceimmune system and induce process of detoxification by inductionof different enzymes (Bhalla et al., 2013). It is found that activecomponents of many EOs could alter different genes expression,ion homeostasis, mitochondrial and plasma membrane functions,signaling and/or metabolic pathways leading to cell cycle arrestand/or cell death (Bhalla et al., 2013; Saad et al., 2013; Raut andKaruppayil, 2014; Greay and Hammer, 2015).

There are scarce literature data concerning cytotoxic activitiesof EOs of some other Nepeta species with considerable amounts ofdiverse nepetalactones (Shakeri et al., 2016; Tsuruoka et al., 2012; Kahkeshani et al., 2014) or germacrene D (Shakeri et al., 2014), and1,8-cineol (Kahkeshani et al., 2014). However, detailed knowledgeabout the mode of action of these EOs is still lacking. In this studywe describe the cytotoxic effects of $\mathrm{N}$. rtanjensis EO, and explore thetype of cell death it induces, the cell cycle phase it affects and thegenes expression of which it alters. These intricate information areparticularly important for evaluating the application possibilities, and facilitating implementation of N. rtanjensis EO in anticancer therapies.

\section{Materials and methods}

\subsection{Plant material and essential oil preparation}

Plants of Nepeta rtanjensis Diklić \& Milojević were field culti-vated at the Institute for Biological Research "Siniša Stanković”, University of Belgrade, Serbia. Voucher specimens 
are depositedat the Herbarium of the Institute of Botany and Botanical Garden'Jevremovac', Faculty of Biology, Belgrade (16064 BEOU), and at the Department of Plant Physiology, Institute for Biological Research "S.Stanković", University of Belgrade, Serbia. Aerial parts of flowering plants flowering plants were collected in July 2014, air-dried at room temperatureuntil constant mass, mechanically chopped, and used for the isola-tion of EO as previously described by Ljaljević Grbić et al. (2008), with some modifications. Hydrodistillation was performed for $2 \mathrm{~h}$,in a Clevenger type apparatus connected to a $5 \mathrm{~L}$ Borosilicate GlassFlat Bottom Flask (Isolab, Germany) containing $300 \mathrm{~g}$ of plant mate-rial and 3 L deionized $\mathrm{H} 2 \mathrm{O}$ (Millipore, Billerica, USA). Essential oilextraction procedure, yielding around $0.5 \mu \mathrm{L}$ essential oil per g DW,was repeated 5 times; obtained oils were pulled and further sub-jected to GC analysis. Total yield of essential oils was $750 \mu \mathrm{L}$.

\subsection{Gas chromatography of $N$. rtanjensis essential oil}

Analysis of N. rtanjensis EO was performed by gas chromatog-raphy (GC) using two types of detectors, flame ionization (FID) and mass-spectrometric (MSD) as previously described (Dmitrović et al., 2015). GC-FID analysis of the EO was carried out on an AgilentTechnologies, model 5890A gas chromatograph on HP-5 column $(25 \mathrm{~m} \times 0.32 \mathrm{~mm}$, $0.53 \mu \mathrm{m}$ film thickness). Flow rate of $\mathrm{H} 2$ (carriergas) was $1 \mathrm{~mL} / \mathrm{min}$, while detector and injector temperatures were $300^{\circ} \mathrm{C}$ and $250{ }^{\circ} \mathrm{C}$, respectively. Column was heated linearly from $40^{\circ} \mathrm{C}$ to $260^{\circ} \mathrm{C}$ and held at $260^{\circ} \mathrm{C}$ for $10 \mathrm{~min}$. Quantification wasperformed using area percent reports as a base. The same analyti-cal conditions as those mentioned for GC-FID were used for GC-MSanalysis, which was carried out on HP G 1800 C Series II GCD system (Hewlett- 
Packard, Palo Alto, CA, USA) attached to a HP- 5MS column $(30 \mathrm{~m} \times 0.25 \mathrm{~mm}, 0.25 \mu \mathrm{m}$ film thickness). Helium was a carriergas $(1 \mathrm{~mL} / \mathrm{min}$ flow rate), while the transfer line was heated at $260{ }^{\circ} \mathrm{C}$. Mass spectra were acquired in EI mode $(70 \mathrm{eV})$ in $\mathrm{m} / \mathrm{z}$ range $40-450$. Identification of constituents was performed by compar-ison of their mass spectra to those from Wiley275 and NIST/NBSlibraries, using different search engines. Experimental values forretention indices were determined using calibrated AutomatedMass Spectral Deconvolution and Identification System Software(AMDIS ver. 2.1, National Institute of Standards and Technology(NIST), Standard Reference Data Program, Gaithersburg, MD, USA),and by comparison with the available literature (Adams, 2007).

\subsection{Cell culture}

Human cervix carcinoma cells (HeLa), human breast cancercells (MDA-MB-231), human colon carcinoma cells (LS-174), lungadenocarcinoma cells (A549), human myelogenous leukemia cells (K562) and human fetal lung fibroblast cells (MRC-5) were main-tained in the Roswell Park Memorial Institute (RPMI) 1640 nutrientmedium (Sigma Chemicals Co., USA). RPMI 1640 nutrient mediumwas prepared in sterile deionized water, supplemented with peni-cillin $(192 \mathrm{U} / \mathrm{mL})$, streptomycin $(200 \mu \mathrm{g} / \mathrm{mL}), \quad 4-(2-$ hydroxyethyl)piperazine-1-ethanesulfonic acid (HEPES) $(25 \mathrm{mM})$, L-glutamine (3 $\mathrm{mM})$ and $10 \%$ of heat-inactivated fetal calf serum (FCS) $(\mathrm{pH} 7.2)$. The cells were grown at $37 \circ \mathrm{C}$ in $5 \%$ CO2and humidified air atmo-sphere. 


\subsection{Cytotoxic activity}

Cytotoxicity of the investigated N. rtanjensis EO was determinedusing the 3-(4,5dimethylthiazol-2yl)-2,5-diphenyltetrazoliumbromide (MTT) assay (Supino, 1995). Experiments were performedon five tumor cell lines (HeLa - human cervix carcinoma cells, A549 - lung adenocarcinoma cells, LS-174 - human colon cancercells, K562 - human myelogenous leukemia cells, MDA-MB-231- human breast cancer cells) and one normal cell line (MRC-5- human fetal lung fibroblast cells). Briefly, cells were seeded in96-well cell culture plates in culture medium (RPMI 1640) andgrown for $24 \mathrm{~h}$. Stock solution of the investigated EO was made in DMSO at concentration of $10 \mu \mathrm{L} / \mathrm{mL}$ and was afterwards diluted with the nutrient medium to the desired final concentrations (inrange up to 0.1 $\mu \mathrm{L} / \mathrm{mL}$ ). Solutions of various concentrations of theexamined EO were added to the wells, except the control wellswhere only nutrient medium was added. All treatments weredone in triplicate. Cells were incubated (CO2incubator 220, FlowLaboratories) for $72 \mathrm{~h}$ with the investigated $\mathrm{N}$. rtanjensis EO. Afterincubation, $20 \mu \mathrm{L}$ of MTT solution, $5 \mathrm{mg} / \mathrm{mL}$ in phosphate buffersolution (PBS), pH 7.2 were added to each well. Samples wereincubated for $4 \mathrm{~h}$ at $37{ }^{\circ} \mathrm{C}$, with $5 \% \mathrm{CO} 2$ in humidified atmosphere.Formazan crystals were dissolved in 100 $\mu \mathrm{L}$ of $10 \%$ sodium dodecylsulfate (SDS). Absorbance was recorded on an enzyme linkedimmunosorbent assay (ELISA) reader (ThermoLabsystems Multi-skan EX 200-240 V) after $24 \mathrm{~h}$ at $570 \mathrm{~nm}$. Concentration IC50wasdefined as the concentration of EO producing $50 \%$ inhibition of cellsurvival, and was determined from the representative cell survivaldiagrams. Cisplatin (CDDP) was used as a standard cytotoxic agent.CDDP stock solution was made in $0.9 \% \mathrm{NaCl}$ at concentration of $3.3 \mathrm{mM}$ and afterwards diluted with nutrient medium to desiredfinal concentrations (in range up to $100 \mu \mathrm{M}$ ). 


\subsection{Morphological analysis}

Morphological analyses were performed by:

\section{A.) Light microscopy}

The morphology of the HeLa, LS-174 and MRC-5 cells was mon-itored using an inverted microscope (Carl Zeiss, Jena, Germany,magnification 78.75-fold) equipped with a digital camera (Olimpus). Following $72 \mathrm{~h}$ treatment with EO or control (nutritionmedium), changes in cellular morphology of the cell lines wereobserved and documented.

-Fluorescent microscopy

Morphological characteristics of HeLa cells' death induced bythe treatment with investigated EO were analyzed after staining ofthe treated cells with a mixture of acridine orange (AO) and ethidium bromide (EB): $0.3 \mathrm{mg} / \mathrm{mL} \mathrm{AO}$ and $0.3 \mathrm{mg} / \mathrm{mL}$ EB in PBS solution (Banada et al., 1996). Briefly, $1 \times 10^{5}$ of HeLa cells were seededon glass slide in Petri dishes, and treated for $24 \mathrm{~h}$ and $48 \mathrm{~h}$ with $0.5 \times \mathrm{IC}_{50}, \mathrm{IC}_{50}$, and $1.5 \times \mathrm{IC}_{50}$ concentrations of $\mathrm{EO}$ (determined for $48 \mathrm{~h}$ treatment). The cells were then stained with $10 \mu \mathrm{L}$ of a mixture of working concentration of $\mathrm{AO} / \mathrm{EB}$, and observed in the next 30 min under a fluorescence microscope Axio Observer Z1, using AxioVision imaging software (Carl Zeiss MicroImaging GmbH). Allused chemicals were purchased from Sigma Aldrich.

\subsection{Analysis of gene expression by real-time PCR}

For total RNA isolation HeLa cells were lysed using TRIREAGENT ${ }^{\circledR}$ BD kit (SigmaAldrich, St. Louis, USA) $24 \mathrm{~h}$ after thetreatment with N. rtanjensis EO in concentrations equal 
to $\mathrm{IC}_{50}$ and $1.5 \times \mathrm{IC}_{50}$ values (determined for $48 \mathrm{~h}$ treatment). cDNA synthesis from total RNA $(2 \mu \mathrm{g})$ was performed using random primers and MultiScribe ${ }^{\mathrm{TM}}$ Reverse Transcriptase from

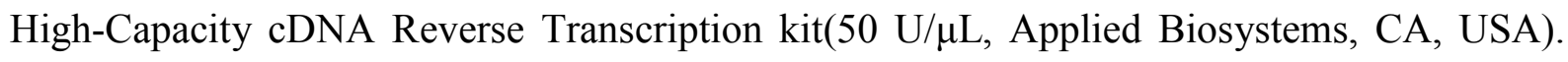
Target transcripts $B a x, B c l-2, p 53$ and $S k p 2$ were detected using quantitative real-time PCR (qRT-PCR) (TaqMan ${ }^{\circledR}$ Gene Expression Assays and TaqMan ${ }^{\circledR}$ Gene Expression Master Mix, Applied Biosystems, CA, USA). To exclude variations arising from different inputs of total mRNA to the reaction, data were normalized to an internal housekeeping gene, glyceraldehyde-3-phosphate dehydrogenase (GAPDH). Non-template controls were included in each amplification mixture. PCR reactions were performed on ABI Prism 7700 Sequence Detection System (Applied Biosystems, CA, USA) and the fluorescence thefluorescence was monitored in real time. The thermal cycling conditions comprised of initial denaturation step at $95^{\circ} \mathrm{C}$ for 10 minfollowed by 40 cycles of denaturation $\left(15 \mathrm{~s}\right.$ at $\left.95^{\circ} \mathrm{C}\right)$ and annealing/extension $\left(1 \mathrm{~min}\right.$ at $\left.60{ }^{\circ} \mathrm{C}\right)$ in a final volume of $20 \mu \mathrm{L}$. All thereactions were performed in triplicate and the data representmean \pm S.E. of three independent experiments. Data were analyzed using the classical delta-delta-Ct method.

2.7. Cell cycle analysis

Quantitative analysis of cell cycle phase distribution was performed by flowcytometric analysis of DNA content in fixed HeLa cells, after staining with propidium iodide (PI) (Ormerod, 1994).

Cells were seeded at a density of $2 \times 105$ cells/well in 6-wellplates and grown in nutrition medium. After $24 \mathrm{~h}$ cells were con-tinually exposed to EO at concentrations that 
corresponded to $0.5 \times \mathrm{IC}_{50}, \mathrm{IC}_{50}$ and $1.5 \times \mathrm{IC}_{50}$ (determined for $48 \mathrm{~h}$ treatment). Control cells were incubated only in nutrient medium. After $48 \mathrm{~h}$ of continual treatment cells were collected by trypsinization, washed twice with ice-cold PBS, and fixed for $30 \mathrm{~min}$ in $70 \%$ EtOH. After fixation cells were washed again with PBS, and incubated with RNaseA(1 $\mathrm{mg} / \mathrm{mL}$ ) for $30 \mathrm{~min}$ at $37{ }^{\circ} \mathrm{C}$. Cells were than stained with PI (atconcentration of $400 \mu \mathrm{g} / \mathrm{mL}$ ) 15 min before the flow-cytometric analysis. Cell cycle phase distribution was analyzed using a fluorescence activated sorting cells (FASC) Calibur Becton Dickinsonflow cytometer and Cell Quest Pro computer software.

\subsection{Statistical analysis}

Data of cytotoxic activity are shown as mean \pm S.D. GraphPadPrism V5.04 (GraphPad Software, San Diego, CA) was used to compare means by two way analysis of variance (ANOVA) in analysis ofgene expression data. When an overall statistically significant difference was observed, post-tests were performed to compare pairsof treatments, using the Bonferroni method to adjust the p-valuefor multiple comparisons. Differences were considered significantif $\mathrm{p}<0.05$. P-values for each analysis are indicated in figure legends. 


\section{Results and discussion}

Essential oils from aromatic and medicinal plants are mainly composed of terpenes and terpenoids, phenylpropanoids andaliphatic components (Bakkali et al., 2008; Bhalla et al., 2013). Chemical analysis revealed that $N$. rtanjensis EO is especially rich inmonoterpenoids, mainly trans,cis-nepetal actone which represents $71.66 \%$ of EO (Table 1). Other stereoisomer, cis,trans-nepetalactone constitutes $17.21 \%$ of the EO. In total, nepetalactone is the majorconstituent in $N$. rtanjensis EO with $88.87 \%$, and minor components are $\alpha$-pinene (3.28\%), 2-metoxy-para-cresol (1.85\%), $\alpha$-copaene( $0.86 \%)$, etc. (Table 1).

Results of the cytotoxic activity assay (shown in Fig. 1 as representative cell survival diagrams) indicate that the investi-gated EO after $72 \mathrm{~h}$ of incubation showed a dose-related cytotoxic activity on all analyzed cell lines in the tested range of concentrations. The highest cytotoxicity was determined for $\mathrm{HeLa}\left(\mathrm{IC}_{50}=0.050 \pm 0.017 \mu \mathrm{L} / \mathrm{mL}\right), \mathrm{K} 562\left(\mathrm{IC}_{50}=0.052 \pm\right.$ $0.003 \mu \mathrm{L} / \mathrm{mL})$ and $\mathrm{A} 549\left(\mathrm{IC}_{50}=0.064 \pm 0.009 \mu \mathrm{L} / \mathrm{mL}\right)$ cells after $72 \mathrm{~h}$ treatment,while $\mathrm{IC}_{50}$ values were $0.093 \pm 0.009 \mu \mathrm{L} / \mathrm{mL}$ for $\mathrm{LS}-174$ cells and $0.097 \pm 0.003 \mu \mathrm{L} / \mathrm{mL}$ for MDA-MB231 cells. The MRC-5 cell line was the least sensitive to the treatment with $\mathrm{EO}$ and $\mathrm{IC}_{50}$ was not reached within the investigated range of concentrations (up to $0.1 \mu \mathrm{L} / \mathrm{mL}$ ). Cisplatin was used as a positive control and for $72 \mathrm{~h}$ treatment exhibited the $\mathrm{IC}_{50}$ values in the following concentration range $0.99-4.29 \mu \mathrm{g} / \mathrm{mL}$ in the investigated cell lines. $\mathrm{IC}_{50}$ values of some other tested EOs obtained from various Nepeta species ranged from $10-50 \mu \mathrm{g} / \mathrm{mL}$ (Tsuruoka et al., 2012; Kahkeshani et al., 2014; Shakeri et al., 2014, 2016). 


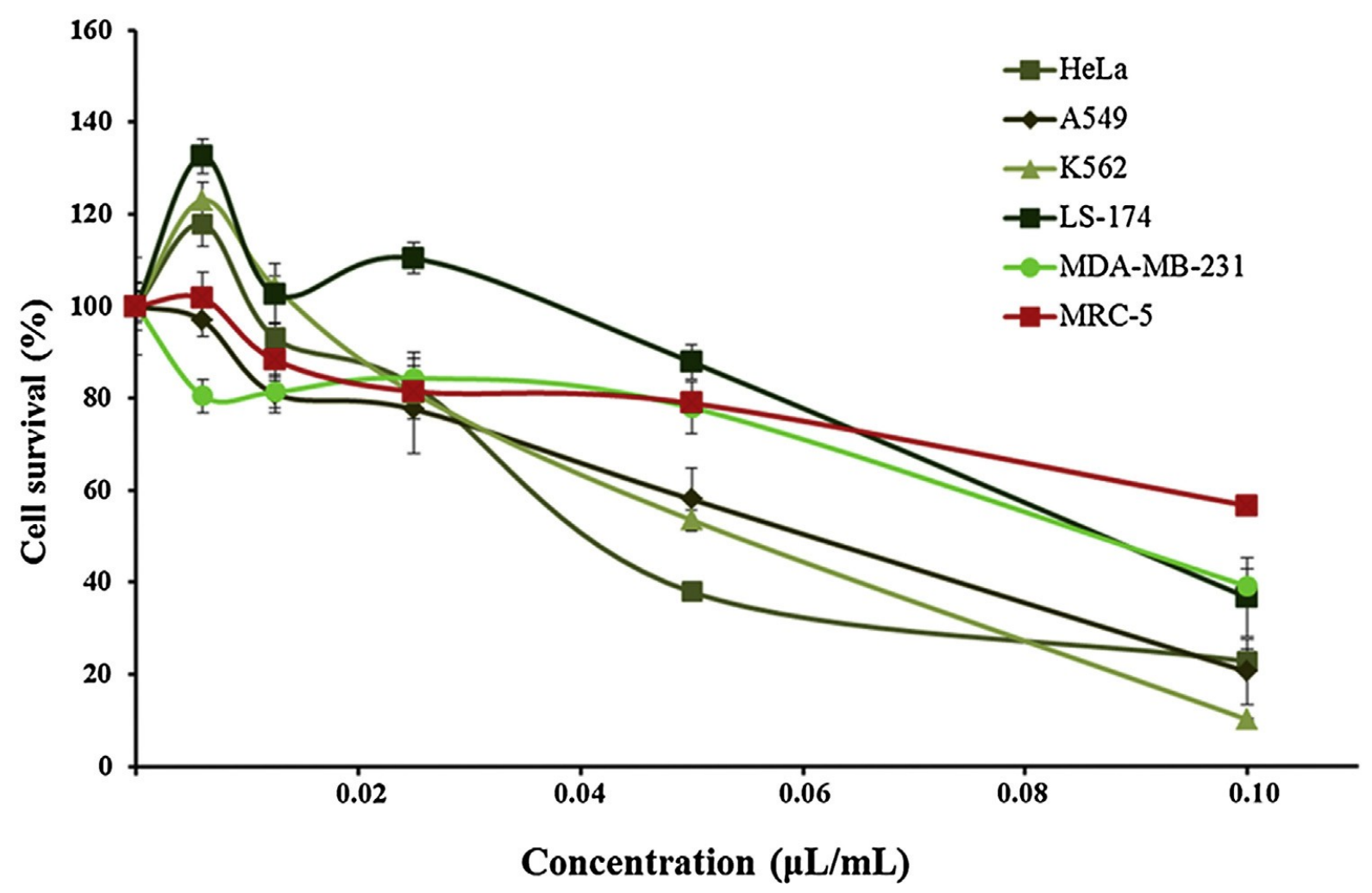

Fig. 1. Representative diagrams of cells survival after $72 \mathrm{~h}$ of continual N. rtanjensis EO action. Data represent mean \pm S.D. of a representative experiment performed intriplicates

Table 1

The chemical composition of $N$. rtanjensis essential oil detected by GC-MS and GCFID analysis.

\begin{tabular}{lllll}
\hline & Constituents & KIE & KIL & $\% \mathrm{~m} / \mathrm{m}$ \\
\hline 1 & $\alpha$-pinene & 931.5 & 932 & 3.28 \\
2 & $\beta$-pinene & 974.7 & 974 & 0.40 \\
3 & 1,8 -cineole & 1030.3 & 1026 & 0.30 \\
4 & $\alpha$-campholenal & 1127.9 & 1122 & 0.18 \\
5 & 2-metoxy-para-cresol & 1218.0 & 1188 & 1.85 \\
6 & cis,trans-nepetalactone & 1364.2 & 1357 & 17.21 \\
7 & $\alpha$-copaene & 1374.7 & 1374 & 0.86 \\
8 & trans,cis-nepetalactone & 1400.3 & 1391 & 71.66 \\
9 & $1,3,3$-trimethyl-5-oxobicyclo[2.2.1]hept-2-yl acetate & 1460.8 & 1449 & 0.30 \\
10 & $\gamma$-cadinene & 1513.9 & 1513 & 0.27 \\
11 & $\delta$-cadinene & 1523.5 & 1522 & 0.74 \\
12 & $\alpha$-calacorene & 1543.8 & 1544 & 0.23 \\
13 & $\alpha$-cadinol & 1657.7 & 1652 & 0.16 \\
14 & cis-14-nor-muurol-5-en-4-one & 1688.8 & 1688 & 0.21 \\
& Total & & & $\mathbf{9 7 . 6 5}$ \\
\hline
\end{tabular}

KIE - experimentally determined Kovats index

$\mathrm{KIL}$ - Kovats index from literature

$\% \mathrm{~m} / \mathrm{m}$ - percentage of component in extract (mass on mass) 
Essential oil from N.sibirica, rich in cis,trans-nepetalactone, showed cytotoxic effectson human leukemia myeloid-derived cell line HL-60 and on stomach adenocarcinoma Kato III, but was not cytotoxic to the lung adenocarcinoma cell line A549 (Tsuruoka et al., 2012). N.rtanjens is EO exhibited a significant cytotoxic effect on the same cancer cell line (A549), as well as on the other type of myeloidleukemia cancer cell line K562. Essential oils of $N$. sintesii and N.menthoides which mainly consists of oxygenated monoterpenes, mostly nepetalactones and 1,8 cineol, showed a potent antiproliferative and strong cytotoxic activity on various tested humancarcinoma cell lines, including HeLa (cervical cancer) and MCF7(breast adenocarcinoma) cells (Kahkeshani et al., 2014; Shakeriet al., 2016). Similar effects on breast carcinoma cell line MCF, as well as on ovarian cancer A2780 cell line was demonstrated for EO of N. ucrainica rich in germacrene-D (Shakeri et al., 2014). According to the reports in the literature, extracts with cytotoxic activity values lower than $30 \mu \mathrm{g} / \mathrm{mL}$ $\left(\mathrm{IC}_{50}<30 \mu \mathrm{g} / \mathrm{mL}\right.$ ), should be considered as good candidates for future anticancer drug development (Suffness and Pezzuto, 1990; de Oliveira et al., 2015; Shakeriet al., 2016). It is important to point out the observed selectivityof N. rtanjensis EO towards some tumor cell lines (HeLa, K562 and A549) in comparison to investigated normal fibroblast cells (MRC-5, IC50> $0.1 \mu \mathrm{L} / \mathrm{mL}$ ). A similar selectivity between cancer cell lines and a normal cell line (HUVEC) was demonstrated by Shakeri et al. (2016) for EO of $N$. sintenisii, while EO of $N$. menthoides was cytotoxic on cancer and normal cells as well (Kahkeshaniet al., 2014). It is considered as important that chemotherapeutic drugs should target only tumor cells exhibiting cytotoxic and/or cytostatic effects with minimal damage to normal cells (Johnstoneet al., 2002). Therefore, EOs with a proven in vitro selectivity toward cancer cells are favorable candidates for future investiga-tions. Thus, the presented results emphasize the significance of 
the possible use of $N$. rtanjensis EO as a candidate for further researchand antitumor drug development.

Since this is, to our knowledge, the first time that cytotoxic activity of $N$. rtanjensis EO has been demonstrated, further investigations were conducted toward determination of the type of cancer cell death it induces. Analysis of morphology of HeLa, LS-174, and MRC-5 cells revealed the appearance of a reduction in cell number as early as $72 \mathrm{~h}$ after addition of the EO (Fig. 2). Cells lost their normal morphology and became rounded (as observed for HeLa and LS-174 cells) which might indicate apoptosis as a type of cellular death (Fig. 2). Apoptosis is a preferable type ofcell death to necrosis, since it does not produce inflammation or damage to normal tissue surrounding the tumor (Johnstone et al.,2002). In order to determine the type of cell death induced by the investigated N. rtanjensis EO, HeLa cells were stained with acridine orange and ethidium bromide and observed under a fluorescence microscope. Representative microphotographs after $24 \mathrm{~h}$ of treatment with the $1.5 \times \mathrm{IC}_{50}$ concentration of $\mathrm{EO}$ determined for $48 \mathrm{~h}\left(\mathrm{IC}_{50}=0.084 \mu \mathrm{L} / \mathrm{mL}\right.$ are presented in Fig.3. Untreated control cells were dense and light green colored. After the $24 \mathrm{~h}$ treatment with the investigated concentration of EO the number of cells was reduced compared to control, cells lost their normal morphology and became rounded. This was followed by the cytoplasmic shrinkage and nuclear condensation and fragmentation, cell membrane blebbing and occurrence of apoptotic bodies (Fig. 3), which are characteristic for apoptosis (Marĩno et al., 2014; Sharma et al., 2010; Westhoff et al., 2014). 


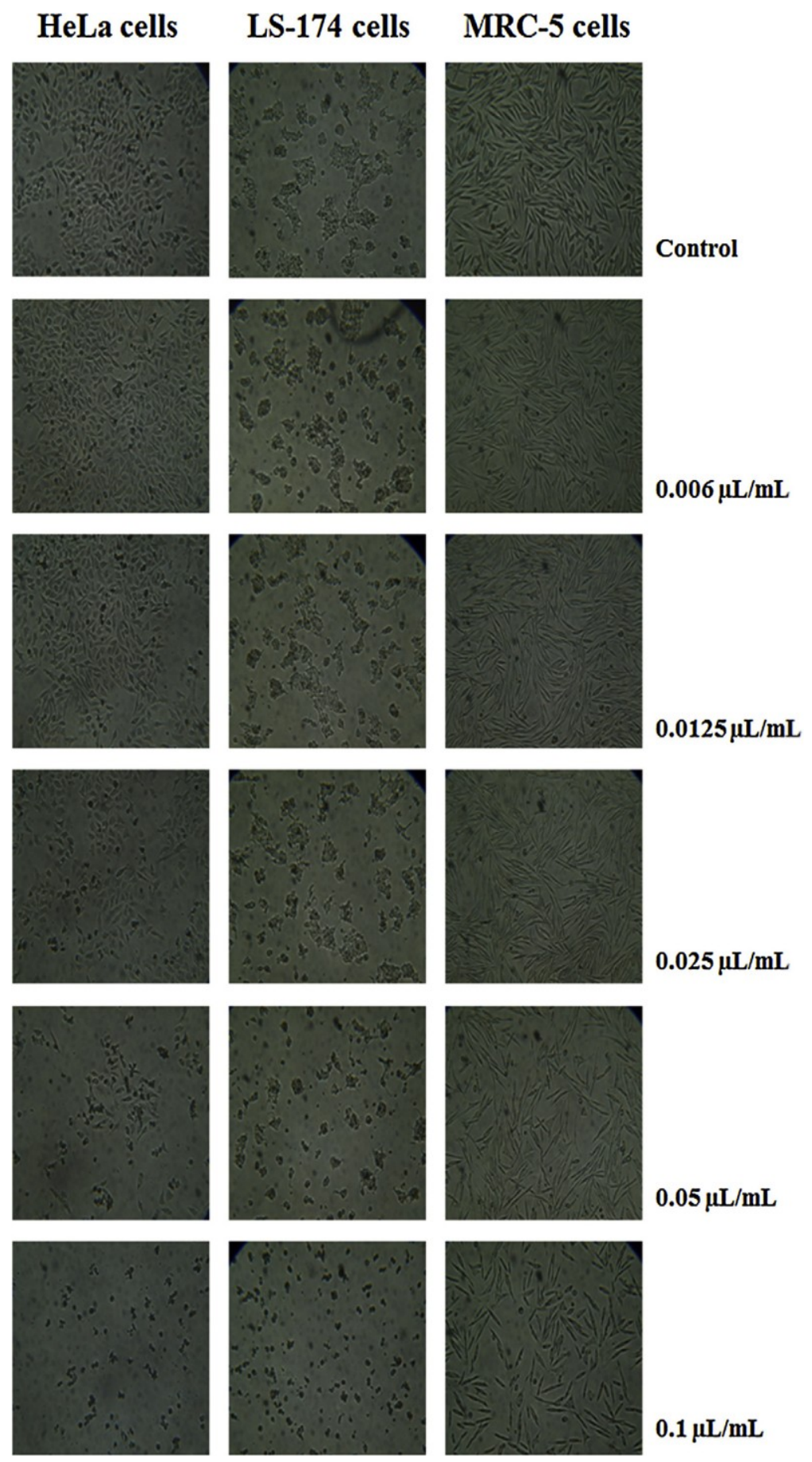

Fig. 2. Morphological changes of treated HeLa, LS-174 and MRC-5 (normal) cells for a $72 \mathrm{~h}$ treatment with N. rtanjensis EO detected by inverted microscope.

Different types of stress may induce cell cycle arrest at different phases and enable maintenance of genomic integrity by initiatingapoptosis (Guichard et al., 2015). In order to 
further clarify thepotential influence of the investigated EO on cell cycle progres-sion, analysis of cell cycle has been assessed on HeLa cells by flowcytometry. Results presented in Fig. 4 indicated that N.rtanjensis EO induced perturbations of the cell cycle of HeLa cells, only at the highest concentration tested $\left(1.5 \times \mathrm{IC}_{50}\right.$ determined for $\left.48 \mathrm{~h}\right)$. The obtained results showed an increase in the percentage of cells in sub-G1 phase (apoptotic), a decrease of percentage of cells in Gland an increase of percentage of cells in the S phase of the cellcycle after $48 \mathrm{~h}$ of continual EO action. The observed potential of $N$. rtanjensis EO to induce cell cycle perturbations and to increasethe number of cells with fragmented DNA indicated its ability toinduce tumor cell apoptosis.

There is increasing evidence that changes in the expression ofmany genes occur due to the cancer cell's response to chemothera-peutic drugs, and according to the numerous literature data, thesemolecular changes are involved in the induction of apoptosis incancer cell lines (Johnstone et al., 2002; Chipuk and Green, 2006;Marĩ no et al., 2014).

Antitumor properties of monoterpenes involve activation ofapoptotic pathways, reduction of prosurvival signals via inter-ruption of the MAPK cascade at several levels, cell cycle arrestand efficiency improvement of radiotherapy (Fernandes, 2015). Apoptosis induced by monoterpenes occurs through both extrinsic (death receptor) and intrinsic (mitochondrial) pathways (Fernandes, 2015). Members of the Bcl-2 family proteins including proapoptotic (e.g. Bax, Bak, p53 upregulated modulator of apoptosis - PUMA, Bad, Bcl-Xs, Bid, Bik, Bim) and antiapoptotic (Bcl-2,Bcl-XL, Bcl-W, Bfl-1, Mcl-1) have a major role in cell survival anddrug sensitivity (Fernandes, 2015), usually by upregulation of proapoptotic and/or downregulation of antiapoptoptic membersof this family (Kalimuthu and Se-Kwon, 2013; Verhaegen et al.,2014). 


\section{HeLa cells}

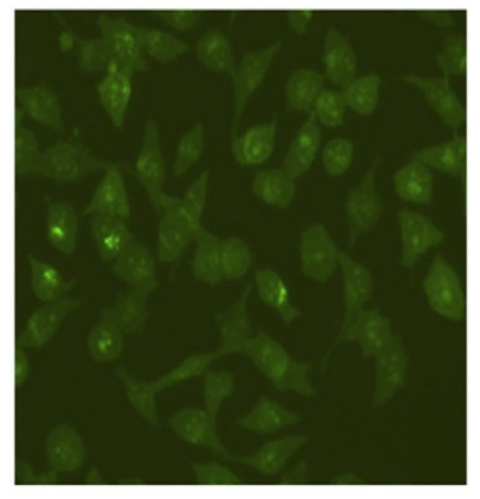

Control

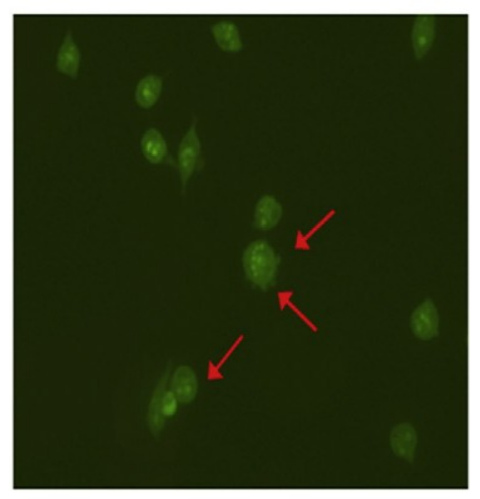

$1.5 \times$ IC50, $24 \mathrm{~h}$

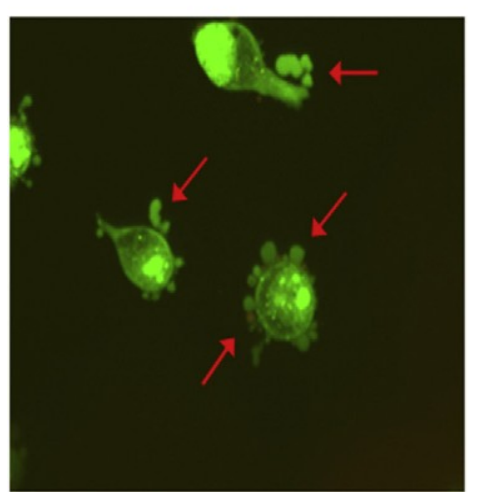

$1.5 \times$ IC50, $24 \mathrm{~h}$

Fig. 3. Morphological changes of HeLa cells treated for $24 \mathrm{~h}$ with N. rtanjensis EO detected by fluorescence microscope. Arrows indicate characteristic cell membrane blebbing and occurrence of apoptotic bodies.

Upregulation of p53 is well documented in apoptosis aswell (Chipuk and Green, 2006; Kalimuthu and Se-Kwon, 2013). Infact, $p 53$ represents a major regulator of apoptosis through sev-eral mechanisms including transcription-dependent functions andtranscriptionindependent activities (Ryan et al., 2001; Johnstoneet al., 2002; Chipuk and Green, 2006; Kalimuthu and Se-Kwon,2013). p53 could initiate apoptosis through activation of 
theproapoptotic Bcl-2 family members or some other genes (i.e. PTEN, Apaf-1, PERP), and by repression of antiapoptotic Bcl-2 proteins (Johnstone et al., 2002; Chipuk and Green, 2006; Kalimuthu and Se-Kwon, 2013). Skp2, an E3 ligase, acts as an oncoprotein by tar-geting p27 for degradation, and is usually overexpressed in tumor cells (Wang et al., 2012; Chan et al., 2014; Chung et al., 2015). Skp2 has been considered as a promising novel therapeutic target for several types of human cancers (Wang et al., 2012; Chan et al., 2014). Recent studies reported down regulation of $S k p 2$ gene expression in drug-induced apoptosis (Huang et al., 2011; Sun et al., 2012; Chunget al., 2015).

In order to elucidate the mechanisms underlying the apopto-sis induced by $N$. rtanjensis EO, the changes in Bax, Bcl-2, p53 and Skp2 gene expression in HeLa cells were analyzed by real timePCR (Fig. 5). The quantitative gene expression analysis showed a general upregulation of Bax mRNA expression, downregulation of $B c l-2$, upregulation of $p 53$ and downregulation of $S k p 2$, all confirming an apoptosis-inducing effect of $N$. rtanjensis EO oil on HeLacells. Similarly to nepetalactone-rich EO, curcumin was shown toreduce the level of Skp2 mRNA in a breast cancer cell line (MDA-MB-231/Her2) (Sun et al., 2012). In human squamous cell lung carcinoma H520 cells, curcumin induced apoptosis by increasing the expression of pro-apoptotic Bax, and by downregulation of anti-apoptotic Bcl-2 and Bcl- $\mathrm{X}_{\mathrm{L}}$, leading to the activation of caspases (Sen et al., 2005). Perillyl alcohol and d-limonene, both belongingto monoterpenes, also influenced the apoptotic pathway causing an increased expression of Bax and decreased expression of Bcl-2(Chaudhary et al., 2009, 2012). Linalool, a natural small moleculemonoterpene, induced apoptosis with activation of p53 and severalcyclin-dependent kinase inhibitors ( $\mathrm{Gu}$ et al., 2010). Lingaiah et al.(2013) demonstrated that the monoterpene myrtenal consider-ably increased p53 expression in cancer-bearing rats and suggestedthat the shown overexpression of p53 plays a crucial role in 
themyrtenal-induced apoptosis. Thymoquinone, monoterpene fromNigella sativa, induced apoptosis in HeLa cells by upregulation ofp53 expression (Yazan et al., 2009), while citral from Zingiber offici-nale (ginger) induced an increase of p53, decrease of Bcl-2, with noeffect on Bax, leading to the apoptosis in endometrial cancer cells (Liu et al., 2012).

Essential oils represent the mixture of numerous constituentshence their cytotoxic activity actually represents a sum of eachindividual activity and all possible impacts including synergies andantagonisms (Lesgards et al., 2014; Bhalla et al., 2013; Shakeri et al., 2016). Easy isolation of monoterpenes from natural sources, theirlow toxicity, as well as the presence of increasing reports of theiranticancer activities and the elucidation of their principal mode ofaction in tumor cells make a good rationale for their potential usein clinical trials (Fernandes, 2015). In this regard, it is noteworthythat even when monoterpenes do not exhibit antitumor effects theycan enhance the activity of other natural products or drugs used inclinical treatment (Fernandes, 2015).
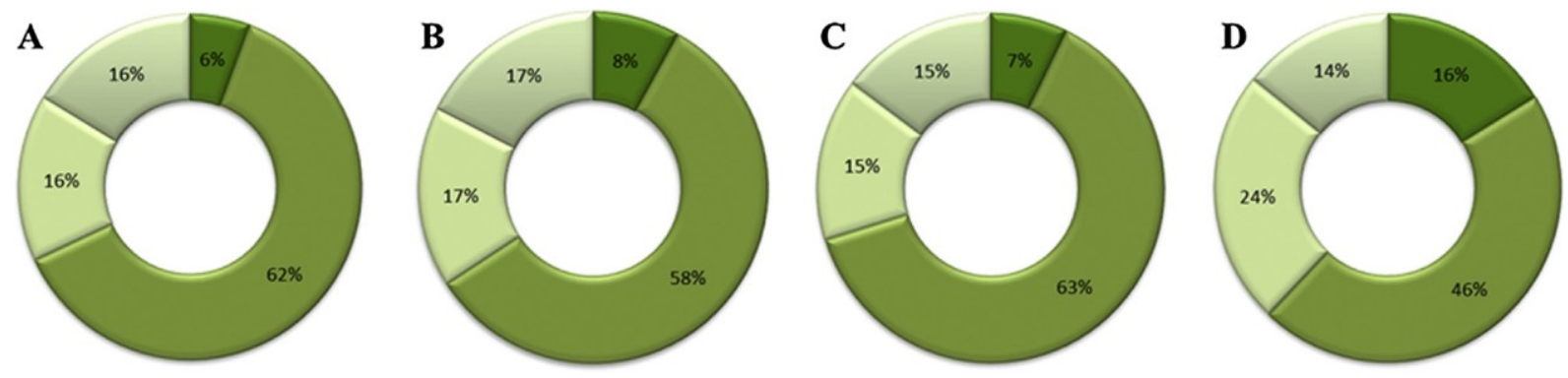

$\square \mathrm{Sub}$ G1 $\square \mathrm{G} 1 \quad \square \mathrm{S} \square \mathrm{G} 2$

Fig. 4. Concentration-dependent effect of N. rtanjensis EO on cell cycle distribution of HeLa cells. Data represent mean of a representative experiment performed in triplicates.A) Control B) $0.5 \times$ IC50C) IC50D) $1.5 \times$ IC50 


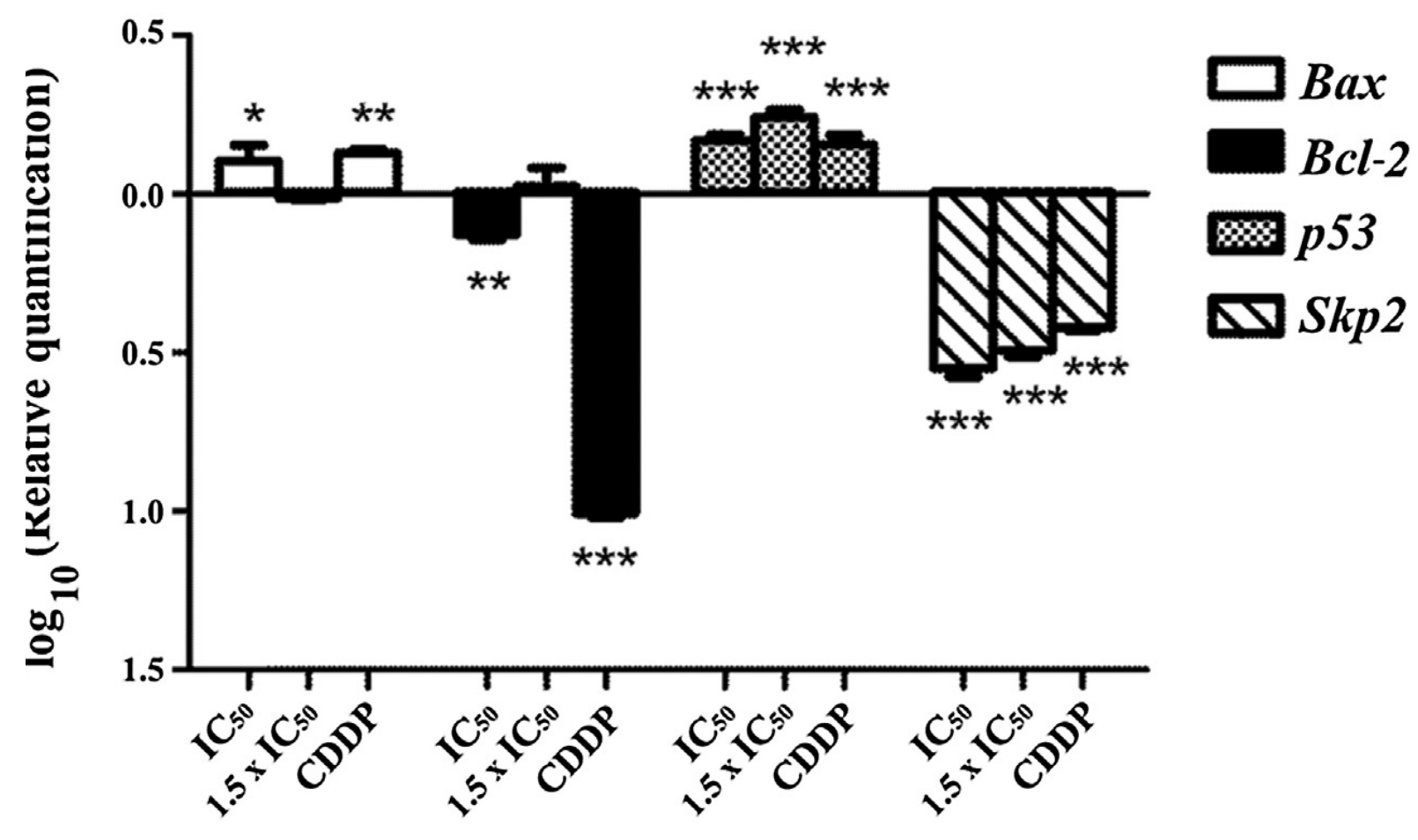

Fig. 5. Analysis of Bax, Bcl-2, p53 and Skp2 mRNA expression after $24 \mathrm{~h}$ of treatment with $\mathrm{N}$. rtanjensis EO at concentrations equal to IC50and $1.5 \times$ IC50. Gene expression levelswere determined by qPCR and normalized to GAPDH. Data represent mean \pm S.E. of three independent experiments performed in triplicates. CDDP - cisplatin (1.8 $\mathrm{g} / \mathrm{mL})$. Asterisks denote statistical significance compared to control (nontreated) cells $\left({ }^{*} \mathrm{p}<0.05 ; * * \mathrm{p}<0.01 ; * * * \mathrm{p}<\right.$ $0.001)$.

The presented data that selective apoptosis induced by EO of $N$. rtanjensis, which is rich in trans,cis-nepetalactone, involves cell cycle phase perturbations and changes in expression levels of Bax, Bcl-2, Skp2 and p53, clearly indicate that N. rtanjens is EO and its major constituent (trans,cis-nepetalactone) should be marked attractive for further investigation and potential anticancertherapy. Considering the obtained results, the concentration of $0.05-0.1$ $\mathrm{L} / \mathrm{mL}$ of $\mathrm{N}$. rtanjensis EO could be recommended forfurther in vitro investigations, especially on human cervix carcinoma cells (HeLa) and human myelogenous leukemia cells (K562), followed by the evaluation of the changes in gene and proteinexpression patterns in cancer-bearing animals. 


\section{Acknowledgements}

This work was supported by the Ministry of Education and Sci-ence of the Republic of Serbia Contracts No. 173024, No. III41026and No. 173021. The authors acknowledge the contribution of DrBranka Uzelac in language improvement.

\section{References}

Adams, R.P., 2007. Identification of Essential Oil Components by GasChromatography/mass Spectrometry. Allured Publishing Corporation, Illinois.

Bakkali, F., Averbeck, S., Averbeck, D., Idaomar, M., 2008. Biological effects ofessential oils? a review. Food Chem. Toxicol. 46 (2), 446-475.

Banada, N.K., Satterfield, W.C., Dunlap, A., Steimer, K.S., Kurrle, R., Finkel, T.H.,1996. Lack of gp120-induced anergy and apoptosis in chimpanzees iscorrelated with resistance to AIDS. Apoptosis 1 (1), 49-62.

Bhalla, Y., Gupta, V.K., Jaitak, V., 2013. Anticancer activity of essential oils: a review.J. Sci. Food Agric. 93 (15), 3643-3653.

Birkett, M.A., Hassanali, A., Hoglund, S., Pettersson, J., Pickett, J.A., 2011. Repellentactivity of catmint, Nepeta cataria, and iridoid nepetalactone isomers againstAfro-tropical mosquitoes, ixodid ticks and red poultry mites. Phytochemistry 72 (1), 109-114. 
Chan, C.H., Morrow, J.K., Zhang, S., Lin, H.K., 2014. Skp2: a dream target in thecoming age of cancer therapy. Cell Cycle 13, 679-680.

Chaudhary, S.C., Alam, M.S., Siddiqui, M.S., Athar, M., 2009. Perillyl alcoholattenuates RasERK signaling to inhibit murine skin inflammation andtumorigenesis. Chem. Biol. Interact. $179(2-3), 145-153$.

Chaudhary, S.C., Siddiqui, M.S., Athar, M., Alam, M.S., 2012. D-Limonene modulatesinflammation, oxidative stress and Ras-ERK pathway to inhibit murine skintumorigenesis. Hum. Exp. Toxicol. 31 (8), 798-811.

Chipuk, J.E., Green, D.R., 2006. Dissecting p53-dependent apoptosis. Cell DeathDiffer. 13 (6), 994-1002.

Chung, Y.K., Or, R.C.H., Lu, C.H., Ouyang, W.T., Yang, S.Y., Chang, C.C., 2015.Sulforaphane down-regulates SKP2 to stabilize p27 KIP1 for inducingantiproliferation in human colon adenocarcinoma cells. J Biosci. Bioeng. 119(1), 35-42.

Diklić, N., 1999. The Red Data Book of Flora of Serbia 1. Extinct and CriticallyEndangered Taxa. In: Stevanović, V. (Ed.). Ministry of Environment of the Republic of Serbia, Faculty of Biology, University of Belgrade, Institute forProtection of Nature of the Republic of Serbia, Belgrade, pp. 153-448.

Dmitrović, S., Perišić, M., Stojić, A., Živković, S., Boljević, J., Nestorović Živković, J.,Aničić, N., Ristić, M., Mišić, D., 2015. Essential oils of two Nepeta species inhibitgrowth and induce oxidative stress in ragweed shoots in vitro. Acta Physiol.Plant. 37, 1-15.

Edris, A.E., 2007. Pharmaceutical and therapeutic potentials of essential oils andtheir individual volatile constituents: a review. Phytother. Res. 20 (4), 308-323.

Fernandes, J., 2015. Antitumor monoterpenes. In: de Sousa, D.P. (Ed.), BioactiveEssential Oils and Cancer. Springer International Publishing, Switzerland, pp.175-200, http://dx.doi.org/10.1007/978-3-319-19144-7. 
Formisano, C., Rigano, D., Senatore, F., 2011. Chemical constituents and biologicalactivities of Nepeta species. Chem. Biodivers. 8 (10), 1783-1818.

Gilani, A.H., Shah, A.J., Zubair, A., Khalid, S., Kiani, J., Ahmed, A., Ahmad, V.U., 2009. Chemical composition and mechanisms underlying the spasmolytic andbronchodilatory properties of the essential oil of Nepeta cataria L. J.Ethnopharmacol. 121 (3), 405-411.

Gkinis, G., Tzakou, O., Iliopoulou, D., Roussis, V., 2003. Chemical composition andbiological activity of Nepeta parnassica oils and isolated nepetalactones. Z.Naturforsch 58c, 681-686.Greay, S.J., Hammer, K.A., 2015. Recent developments in the bioactivity ofmono-and diterpenes: anticancer and antimicrobial activity. Phytochem. Rev.14 (1), 1-6.

Gu, Y., Ting, Z., Qiu, X., Zhang, X.L., Gan, X., Fang, Y., Xu, X., Xu, R., 2010.

Linaloolpreferentially induces robust apoptosis of various leukemia cells viaupregulating p53 and cyclin-dependent kinase inhibitors. Toxicology 268,19-24.

Guichard, A., Humbert, P., Tissot, M., Muret, P., Courderot-Masuyer, C., Viennet, C.,2015. Effects of topical corticosteroids on cell proliferation, cell cycleprogression and apoptosis: in vitro comparison on HaCaT. Int. J. Pharmaceut.479 (2), 422-429.

Huang, H.C., Lin, C.L., Lin, J.K., 2011. 1, 2, 3, 4, 6-penta-O-galloyl- -D-glucose,quercetin, curcumin and lycopene induce cell-cycle arrest in MDA-MB-231and BT474 cells through downregulation of Skp2 protein. J. Agric. Food Chem.59 (12), 6765-6775.

Johnstone, R.W., Ruefli, A.A., Lowe, S.W., 2002. Apoptosis: a link between cancergenetics and chemotherapy. Cell 108 (2), 153-164.

Kahkeshani, N., Razzaghirad, Y., Ostad, S.N., Hadjiakhoondi, A., Shams Ardekani,M.R., Hajimehdipoor, H., Attar, H., Samadi, M., Jovel, E., Khanavi, M., 2014.Cytotoxic, acetylcholinesterase inhibitor and antioxidant activity of Nepetamenthoides Boiss \& Buhse essential oil. J Essent. Oil Bear. P1. 17 (4), 544-552.

Kalimuthu, S., Se-Kwon, K., 2013. Cell survival and apoptosis signaling astherapeutic target for cancer: marine bioactive compounds. Int. J. Mol. Sci. 14(2), 2334-2354. 
Kobaisy, M., Tellez, M.R., Dayan, F.E., Mamonov, L.K., Mukanova, G.S., Sitpaeva, G.T.,Gemejieva, N.G., 2005. Composition and phytotoxic activity of Nepetapannonica L. essential oil. J. Essent. Oil Res. 17 (6), 704-707.

Kumar, V., Mathela, C.S., Tewari, G., Singh, D., 2014. Antifungal activity of Nepetaelliptica Royle ex Benth. oil and its major constituent (7R)-trans,trans-nepetalactone: a comparative study. Ind. Crop. Prod. 55, 70-74.

Lesgards, J.F., Baldovini, N., Vidal, N., Pietri, S., 2014. Anticancer activities ofessential oils constituents and synergy with conventional therapies: a review.Phytother. Res. 28 (10), $1423-$ 1446.

Lingaiah, H.B., Natarajan, N., Thamaraiselvan, R., Srinivasan, P., Periyasamy, B.M.,2013. Myrtenal ameliorates diethylnitrosamine-induced hepatocarcinogenesisthrough the activation of tumor suppressor protein p53 and regulation oflysosomal and mitochondrial enzymes.

Fund. Clin. Pharmacol. 27 (4), 443-454.

Liu, Y., Whelan, R.J., Pattnaik, B.R., Ludwig, K., Subudhi, E., Rowland, H., Claussen,N., Zucker, N., Uppal, S., Kushner, D.M., Felder, M., 2012. Terpenoids fromZingiber officinale (Ginger) induce apoptosis in endometrial cancer cellsthrough the activation of p53. PLoS One 7 (12), e53178.

Ljaljević Grbić, M., Stupar, M., Vukojević, J., Soković, M., Mišić, D., Grubišić, D., Ristić, M., 2008. Antifungal activity of Nepeta rtanjensis essential oil. J. Serb.Chem. Soc. 73 (10), 961-965.

Marĩno, G., Niso-Santano, M., Baehrecke, E.H., Kroemer, G., 2014.Self-consumption: the interplay of autophagy and apoptosis. Nat. Rev. Mol.Cell Bio. 15 (2), 81-94.

Mišić, D., Ghalawenji, N., Grubišić, D., Konjević, R., 2005. Micropropagation andreintroduction of Nepeta rtanjensis, an endemic and critically endangeredperennial of Serbia. Phyton-Ann Rei Bot. 45, 9-20.

Mišić, D.,Šiler, B., Gašić, U., Avramov, S., Živković, S., Nestorović, Živković, J.,Milutinović, M., Tešić, Ž., 2015. Simultaneous UHPLC/DAD/(+/-) HESI-MS/MSanalysis 
of phenolic acids and nepetalactones in methanol extracts of nepetaspecies: a possible application in chemotaxonomic studies. Phytochem. Anal.26 (1), 72-85.

Nestorović Živković, J., Dmitrović, S., Jovanović, V., Živković, S., Božić, D., Aničić, N., Mišić, D., 2016. Allelopathic potential of essential oil of Nepeta rtanjensis?Allelopathy J. 37 (2), 207-219.

Nestorović, J., Mišić, D., Šiler, B., Soković, M., Glamočlija, J.,Ćirić, A., Grubišić, D.,2010. Nepetalactone content in shoot cultures of three endemic Nepeta speciesand the evaluation of their antimicrobial activity. Fitoterapia 81 (6), 621-626.

Ormerod, M.G., 1994. Analysis of DNA-General methods. In: Ormerod, M.G. (Ed.), Flow Cytometry: a Practical Approach. Oxford University Press, New York, pp.119-125.

Raut, J.S., Karuppayil, S.M., 2014. A status review on the medicinal properties ofessential oils. Ind. Crop. Prod. 62, 250-264.

Rigano, D., Arnold, N.A., Conforti, F., Menichini, F., Formisano, C., Piozzi, F.,Senatore, F., 2011. Characterisation of the essential oil of Nepeta glomerataMontbret et Aucher ex Bentham from Lebanon and its biological activities. Nat.Prod. Res. 25 (6), 614-626.

Ryan, K.M., Phillips, A.C., Vousden, K.H., 2001. Regulation and function of the p53tumor suppressor protein. Curr. Opin. Cell Biol. 13 (3), 332-337.

Saad, N.Y., Muller, C.D., Lobstein, A., 2013. Major bioactivities and mechanism ofaction of essential oils and their components. Flavour Frag. J. 28 (5), 269-279.Sakurai, K., Ikeda, K., Mori, K., 1988. Both (4aS, 7S, 7aR)-(+)-nepetalactone and itsantipode are powerful attractants for cats. Agric. Biol. Chem. 52 (9), 2369-2371.

Sen, S., Sharma, H., Singh, N., 2005. Curcumin enhances Vinorelbine mediatedapoptosis in NSCLC cells by the mitochondrial pathway. Biochem. Biophys. Res.Co. 331 (4), 1245-1252.

Shakeri, A., Khakdan, F., Soheili, V., Sahebkar, A., Rassam, G., Asili, J., 2014.

Chemicalcomposition, antibacterial activity, and cytotoxicity of essential oil fromNepeta ucrainica L. spp. kopetdaghensis. Ind. Crop. Prod. 58, 315-321. 
Shakeri, A., Khakdan, F., Soheili, V., Sahebkar, A., Shaddel, R., Asili, J., 2016.

Volatilecomposition, antimicrobial, cytotoxic and antioxidant evaluation of theessential oil from Nepeta sintenisii Bornm. Ind. Crop. Prod. 84, 224-229.

Sharma, A., Cannoo, D.S., 2013. Phytochemical composition of essential oilsisolated from different species of genus Nepeta of Labiatae family: a review.Pharmacophore 4 (6), 181211.

Sharma, M., Agrawal, S.K., Sharma, P.R., Chadha, B.S., Khosla, M.K., Saxena, A.K.,2010.

Cytotoxic and apoptotic activity of essential oil from Ocimum viridetowards COLO 205 cells. Food Chem. Toxicol. 48 (1), 336-344.

Stojanović, G., Radulović, N., Lazarević, J., Miladinović, D., Đoković, D., 2005. Antimicrobial activity of Nepeta rtanjensis essential oil. J. Essent. Oil Res. 17 (5),587-589.

Suffness, M., Pezzuto, J.M., 1990. Assays related to cancer drug discovery. In:Hostettmann, K. (Ed.), Methods in Plant Biochemistry: Assays for Bioactivity.Academic Press, London, pp. $71-133$.

Sun, S.H., Huang, H.C., Huang, C., Lin, J.K., 2012. Cycle arrest and apoptosis inMDA-MB231/Her2 cells induced by curcumin. Eur. J. Pharmacol. 690 (1),22-30.

Supino, R., 1995. MTT assay. In: O’Hare, S., Atterwill, C.K. (Eds.), In Vitro ToxicityTesting Protocols. Humana Press, New Jersey, pp. 137-149. http://dx.doi.org/10.1385/0-89603-282$5: 137$.

Tepe, B., Daferera, D., Tepe, A.S., Polissiou, M., Sokmen, A., 2007. Antioxidantactivity of the essential oil and various extracts of Nepeta flavida Hub.Mor.from Turkey. Food Chem. $103(4), 1358-1364$.

Tsuruoka, T., Bekh-Ochir, D., Kato, F., Sanduin, S., Shataryn, A., Ayurzana, A., Satou,T., Li, W., Koike, K., 2012. The essential oil of Mongolian Nepeta sibirica: a singlecomponent and its biological activities. J. Essent. Oil Res. 24 (6), 555-559. 
Verhaegen, M.E., Mangelberger, D., Weick, J.W., Vozheiko, T.D., Harms, P.W., Nash,K.T., Quintana, E., Baciu, P., Johnson, T.M., Bichakjian, C.K., Dlugosz, A.A.M.E.,Mangelberger, D., Weick, J.W., Vozheiko, T.D., Harms, P.W., Nash, K.T.,Quintana, E., Baciu, P., Johnson, T.M., Bichakjian, C.K., Dlugosz, A.A., 2014.Merkel cell carcinoma dependence on bcl-2 family members for survival. J.Invest. Dermatol. 134 (8), 2241-2250.

Wang, Z., Fukushima, H., Inuzuka, H., Wan, L., Liu, P., Gao, D., Sarkar, F.H., Wei, W.,2012. Skp2 is a promising therapeutic target in breast cancer. Front. Oncol. 1,57.Westhoff, M.A., Brühl, O., Nonnenmacher, L., Karpel-Massler, G., Debatin, K.M.,2014. Killing me SoftlyFuture challenges in apoptosis research. Int. J. Mol. Sci.15 (3), 3746-3767.

Yazan, L.S., Ng, W.K., Al-Naqeeb, G., Ismail, M., 2009. Cytotoxicity of thymoquinone(TQ) from Nigella sativa towards human cervical carcinoma cells (HeLa). J.Pharm. Res. 2 (4), $585-589$.

de Oliveira, P.F., Alves, J.M., Damasceno, J.L., Oliveira, R.A.M., Dias, H.J., Crotti,A.E.M., Tavares, D.C., 2015. Cytotoxicity screening of essential oils in cancer celllines. Rev. Bras. Farmacogn. 25, 183-188. 
Fig 1.

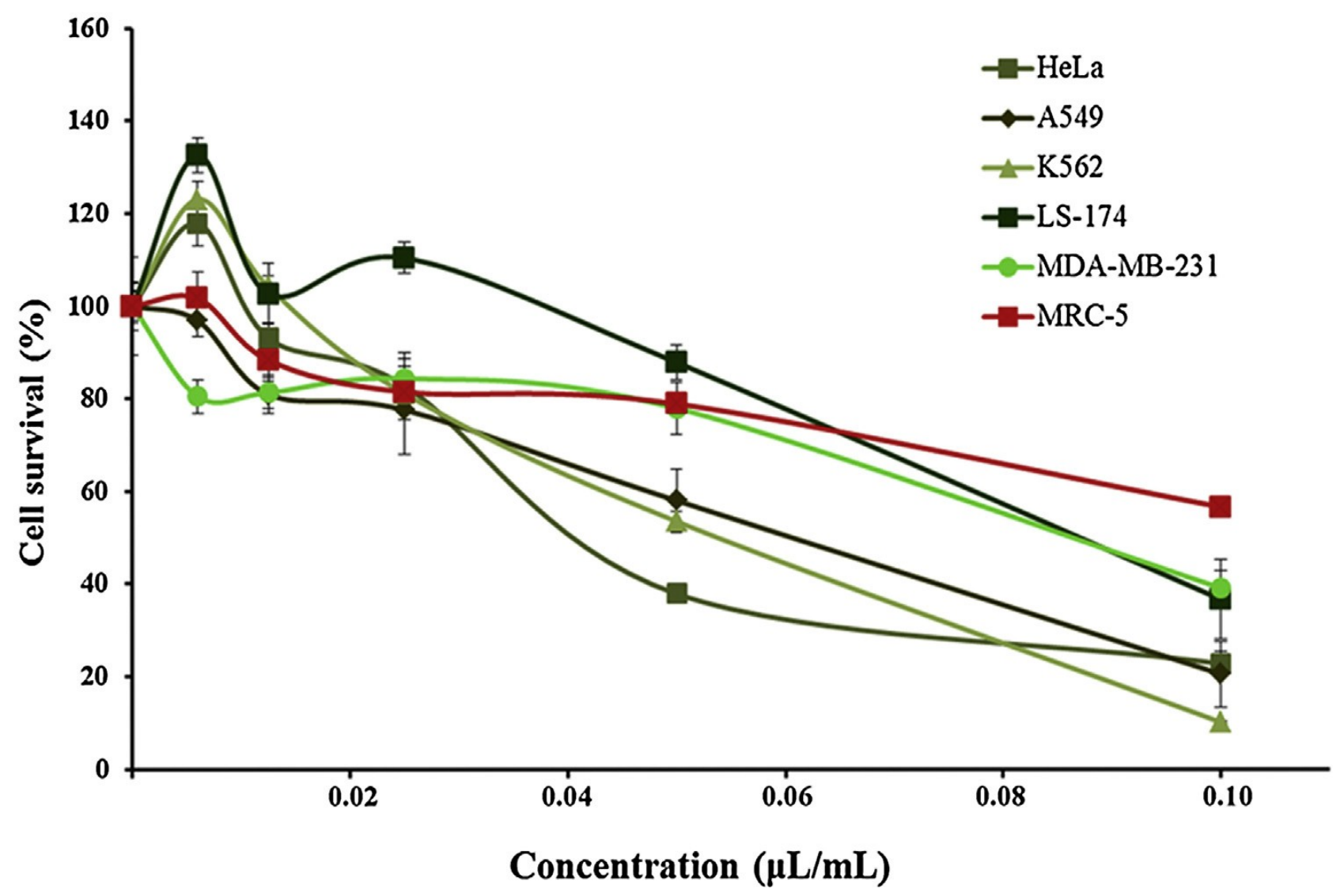

Fig. 1. Representative diagrams of cells survival after $72 \mathrm{~h}$ of continual N. rtanjensis EO action. Data represent mean \pm S.D. of a representative experiment performed intriplicates 
Fig. 2

\section{HeLa cells LS-174 cells MRC-5 cells}
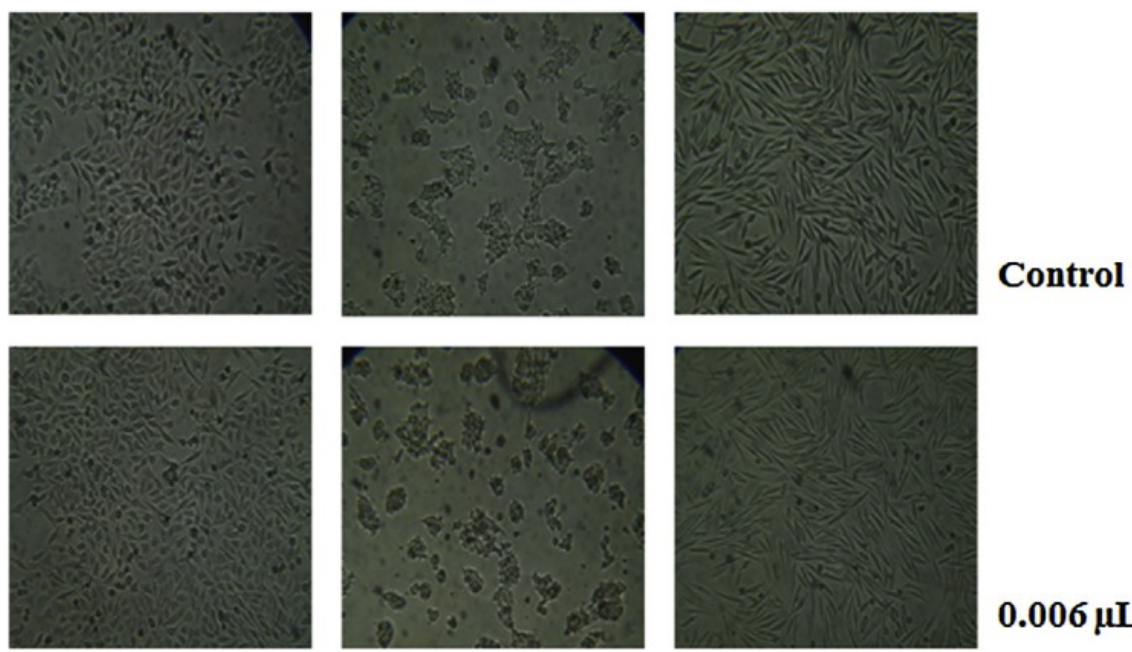

$0.006 \mu \mathrm{L} / \mathrm{mL}$
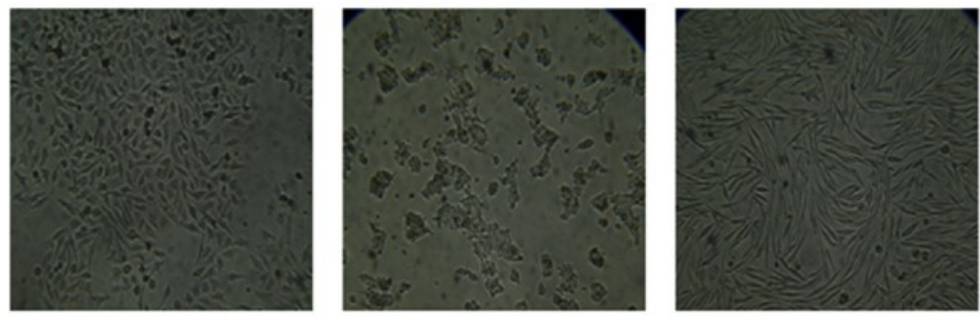

$0.0125 \mu \mathrm{L} / \mathrm{mL}$
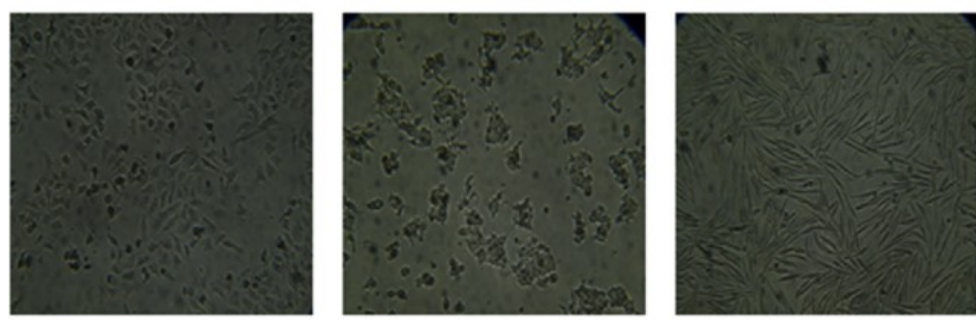

$0.025 \mu \mathrm{L} / \mathrm{mL}$
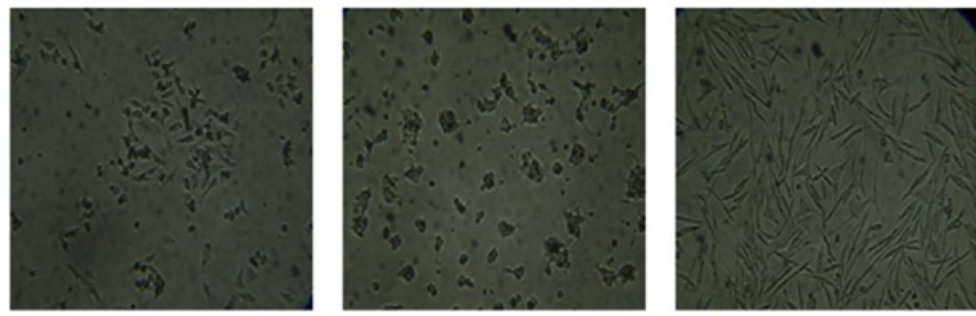

$0.05 \mu \mathrm{L} / \mathrm{mL}$
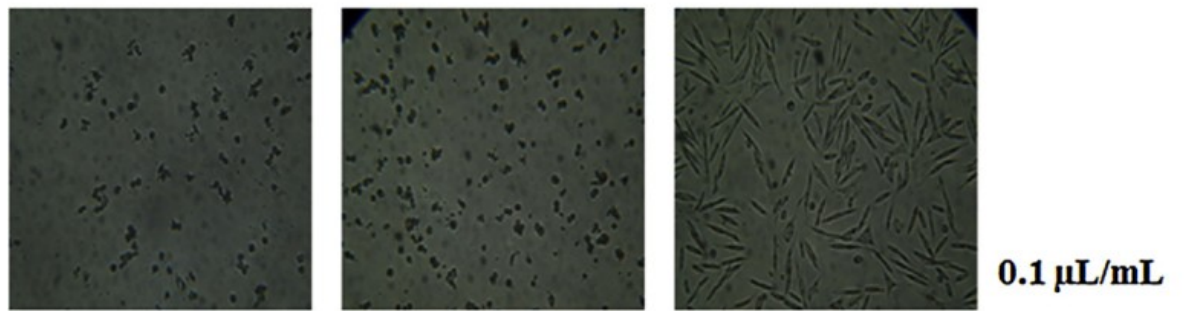

Fig. 2. Morphological changes of treated HeLa, LS-174 and MRC-5 (normal) cells for a $72 \mathrm{~h}$ treatment with N. rtanjensis EO detected by inverted microscope 
Fig. 3

\section{HeLa cells}

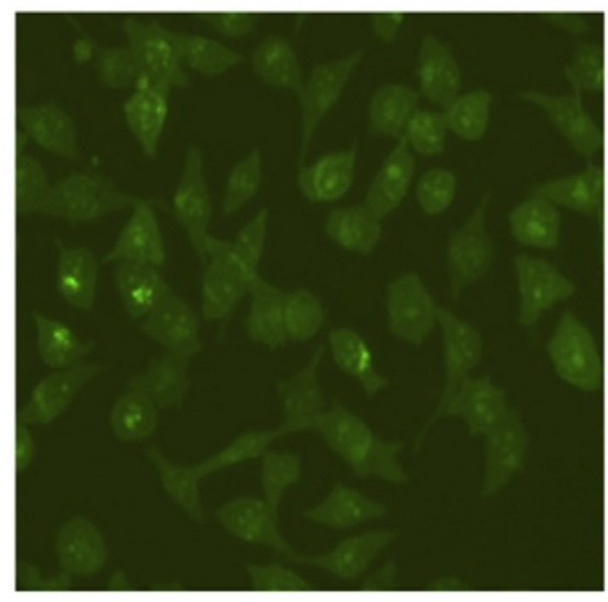

\section{Control}

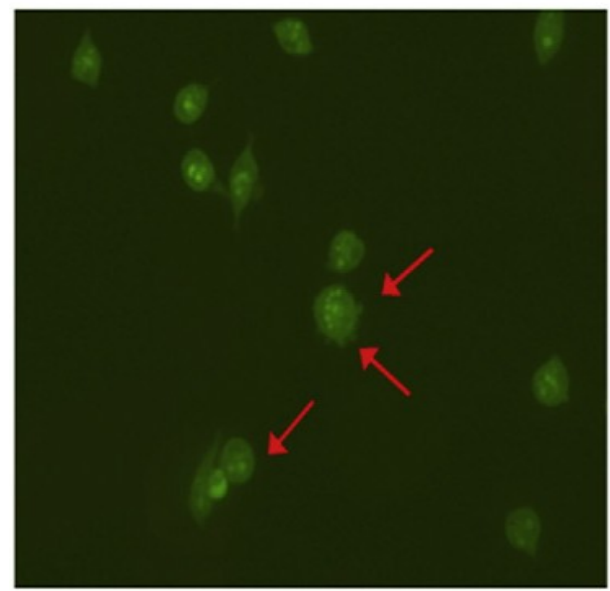

$1.5 \times$ IC50, $24 \mathrm{~h}$

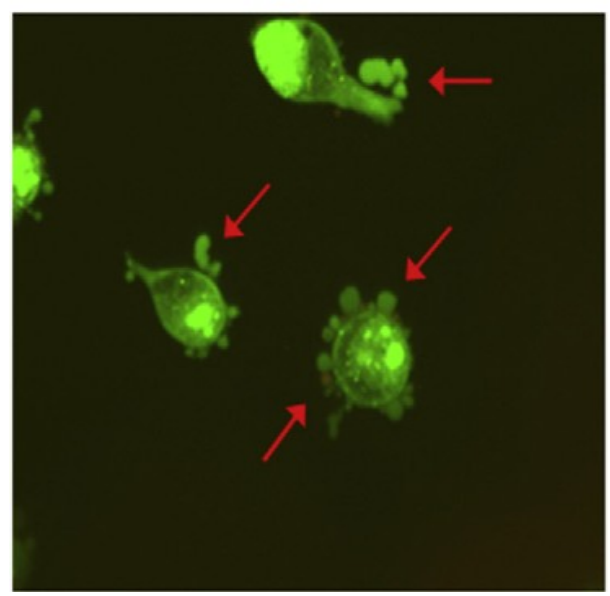

\section{$1.5 \times$ IC50, 24 h}

Fig. 3. Morphological changes of HeLa cells treated for $24 \mathrm{~h}$ with N. rtanjensis EO detected by fluorescence microscope. Arrows indicate characteristic cell membrane blebbing and occurrence of apoptotic bodies. 
Fig 4 .
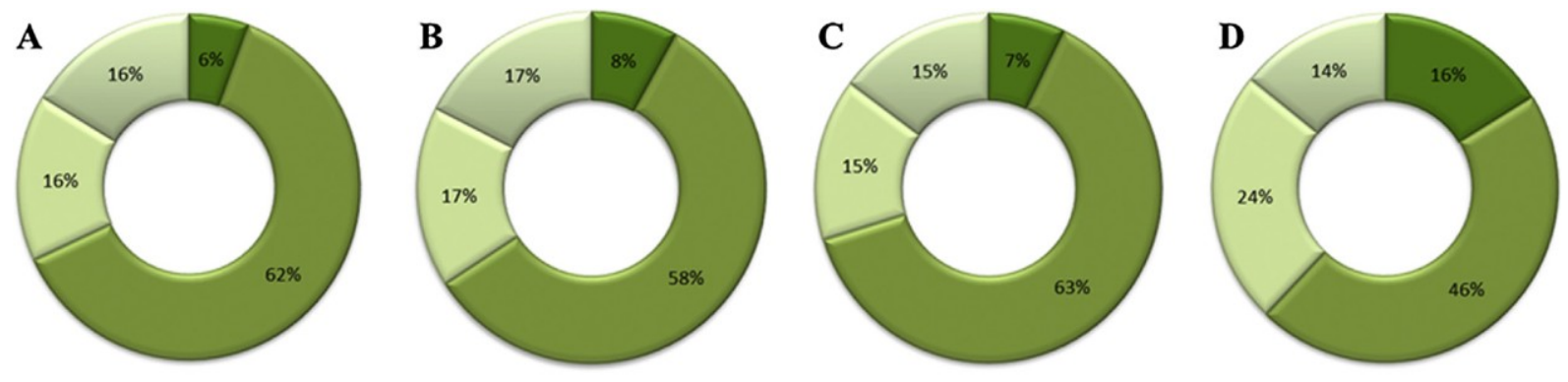

$\square \mathrm{Sub} G 1 \square \mathrm{G} 1 \square \mathrm{S} \square \mathrm{G} 2$

Fig. 4. Concentration-dependent effect of N. rtanjensis EO on cell cycle distribution of HeLa cells. Data represent mean of a representative experiment performed in triplicates. A) Control B) $\left.\left.0.5 \times \mathrm{IC}_{50} \mathrm{C}\right) \mathrm{IC50} \mathrm{D}\right) 1.5 \times \mathrm{IC}_{50}$ 
Fig.5

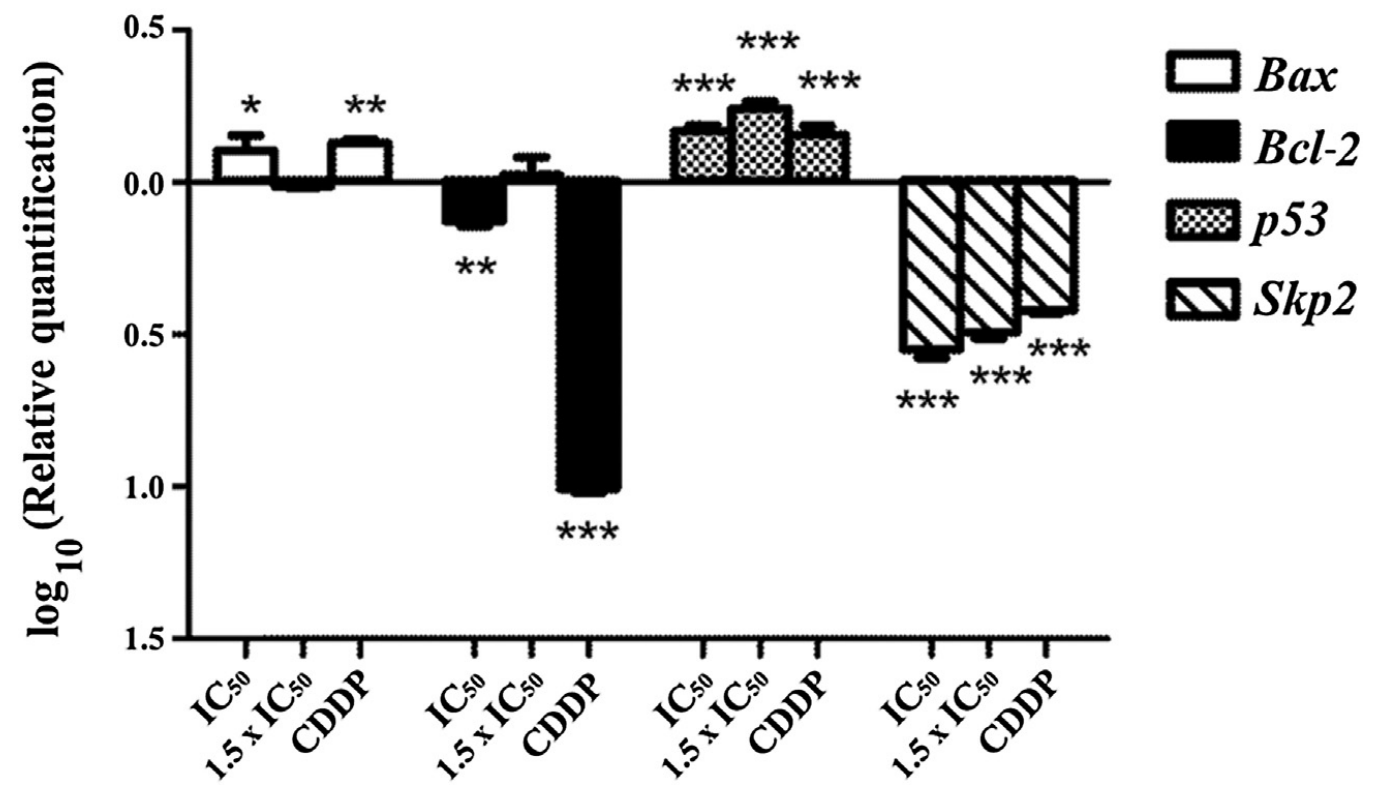

Fig. 5. Analysis of Bax, Bcl-2, p53 and Skp2 mRNA expression after $24 \mathrm{~h}$ of treatment with N. rtanjensis EO at concentrations equal to IC50 and $1.5 \times \mathrm{IC}_{50}$. Gene expression levels were determined by qPCR and normalized to GAPDH. Data represent mean \pm S.E. of three independent experiments performed in triplicates. CDDP - cisplatin $(1.8 \mu \mathrm{g} / \mathrm{mL})$. Asterisks denote statistical significance compared to control (nontreated) cells $(* \mathrm{p}<0.05 ; * * \mathrm{p}<0.01 ; * * \mathrm{p}<0.001)$. 
Table 1.

Table 1

The chemical composition of $N$. rtanjensis essential oil detected by GC-MS and GCFID analysis.

\begin{tabular}{lllll}
\hline & Constituents & KIE & KIL & $\% \mathrm{~m} / \mathrm{m}$ \\
\hline 1 & $\alpha$-pinene & 931.5 & 932 & 3.28 \\
2 & $\beta$-pinene & 974.7 & 974 & 0.40 \\
3 & 1,8 -cineole & 1030.3 & 1026 & 0.30 \\
4 & $\alpha$-campholenal & 1127.9 & 1122 & 0.18 \\
5 & 2-metoxy-para-cresol & 1218.0 & 1188 & 1.85 \\
6 & cis,trans-nepetalactone & 1364.2 & 1357 & 17.21 \\
7 & $\alpha$-copaene & 1374.7 & 1374 & 0.86 \\
8 & trans,cis-nepetalactone & 1400.3 & 1391 & 71.66 \\
9 & $1,3,3$-trimethyl-5-oxobicyclo[2.2.1]hept-2-yl acetate & 1460.8 & 1449 & 0.30 \\
10 & $\gamma$-cadinene & 1513.9 & 1513 & 0.27 \\
11 & $\delta$-cadinene & 1523.5 & 1522 & 0.74 \\
12 & $\alpha$-calacorene & 1543.8 & 1544 & 0.23 \\
13 & $\alpha$-cadinol & 1657.7 & 1652 & 0.16 \\
14 & cis-14-nor-muurol-5-en-4-one & 1688.8 & 1688 & 0.21 \\
& Total & & & 97.65 \\
\hline
\end{tabular}

KIE - experimentally determined Kovats index

KIL - Kovats index from literature

$\% \mathrm{~m} / \mathrm{m}$ - percentage of component in extract (mass on mass) 